\title{
Extraction of Trypanosoma cruzi DNA from food: a contribution to the elucidation of acute Chagas disease outbreaks
}

\author{
Renata Trotta Barroso Ferreiraa ${ }^{[1],[2], ~ A l i n e ~ M a r t i n s ~ M e l a n d r e ~}{ }^{[2],}$ Maria Luiza Cabral[2], \\ Maria Regina Branquinho ${ }^{[2]}$, Paola Cardarelli-Leite ${ }^{[2]}$
}

[1]. Programa de Pós-Graduação em Vigilância Sanitária, Instituto Nacional de Controle de Qualidade em Saúde, Fundação Oswaldo Cruz, Rio de Janeiro, Rio de Janeiro, Brasil. [2]. Instituto Nacional de Controle de Qualidade em Saúde, Fundação Oswaldo Cruz, Rio de Janeiro, Rio de Janeiro, Brasil.

\begin{abstract}
Introduction: Before 2004, the occurrence of acute Chagas disease (ACD) by oral transmission associated with food was scarcely known or investigated. Originally sporadic and circumstantial, ACD occurrences have now become frequent in the Amazon region, with recently related outbreaks spreading to several Brazilian states. These cases are associated with the consumption of açai juice by waste reservoir animals or insect vectors infected with Trypanosoma cruzi in endemic areas. Although guidelines for processing the fruit to minimize contamination through microorganisms and parasites exist, açai-based products must be assessed for quality, for which the demand for appropriate methodologies must be met. Methods: Dilutions ranging from 5 to 1,000 T. cruzi CL Brener cells were mixed with $2 \mathrm{~mL}$ of acai juice. Four Extraction of T. cruzi DNA methods were used on the fruit, and the cetyltrimethyl ammonium bromide (CTAB) method was selected according to JRC, 2005. Results: DNA extraction by the CTAB method yielded satisfactory results with regard to purity and concentration for use in PCR. Overall, the methods employed proved that not only extraction efficiency but also high sensitivity in amplification was important. Conclusions: The method for T. cruzi detection in food is a powerful tool in the epidemiological investigation of outbreaks as it turns epidemiological evidence into supporting data that serve to confirm T. cruzi infection in the foods. It also facilitates food quality control and assessment of good manufacturing practices involving acai-based products.
\end{abstract}

Keywords: Chagas disease. Trypanosoma cruzi. Euterpe (açai). PCR detection. Food analysis.

\section{INTRODUCTION}

In Brazil, both inside and outside the Amazon region, several cases of acute Chagas disease (ACD) have been recorded as an outbreak characterized by a group of individuals gathered in one place who, by ingesting the same type of food, became sick almost simultaneously with fever and general manifestations of a systemic infection ${ }^{(1)}$.

Until the year 2004, the occurrence of ACD by oral transmission, as associated with food consumption, constituted a scarcely known or investigated event. For the same reason, what was originally considered a sporadic and circumstantial occurrence has now become frequent in the Amazon region, which is associated with the occurrence of recent outbreaks in several Brazilian states ${ }^{(2)}$. Recent cases of ACD in Brazil are related to the consumption of açai juice where the contamination of the fruit itself or the pulp occurs through waste reservoir

Corresponding author: Renata Trotta Barroso Ferreira.

e-mail: renata.trotta@incqs.fiocruz.br

Received 18 December 2015

Accepted 5 April 2016 animals or insect vectors infected with Trypanosoma cruzi in endemic areas ${ }^{(3)(4)(5)}$.

Açai (Euterpe oleracea Mart.) is a typical and popular berry fruit of the Amazon region in Northern Brazil, which in recent years has gained importance due to the health benefits associated with its phytochemical composition and antioxidant capacity.

Brazil is the world's largest producer, consumer, and exporter of açai. This fruit is marketed and consumed by the local people in the producing areas of Pará, Maranhão, Amapá, Rondônia, and Acre, which together comprise a distinct region considered endemic for the disease ${ }^{(6)}(7)$. With the increasing growth in commerce, not only has the consumption of the product spread across larger Brazilian cities, but it is now also being exported to America, Japan, China, and some European countries ${ }^{(7)}$.

The Ministry of Agriculture and Supply, through Normative Instruction number 1 of January 07, 2000, issued the technical regulation for setting the standards of identity and quality for fruit pulp, which includes acai pulp ${ }^{(8)}$. Pertinently, the pulp should be obtained from fruit that is fresh, sound, mature, and free of soil, dirt, parasites, and microorganisms that can render the product unfit for consumption ${ }^{(8)}$.

Although the guidelines for the processing of the fruit have been established with a view to minimize contamination 
through microorganisms and parasites, it is necessary to assess the quality of acai-based products, for which appropriate methodologies must be adopted ${ }^{(9)}$.

Several recommendations and incentives on research methodologies for the detection of T. cruzi in food exist ${ }^{(2)}(10)$; however, fully developed methods aimed at the detection of parasites in food are still lacking not only for furnishing a response to epidemiological investigations in cases of outbreaks, but also for controlling the quality of commercialized products.

Molecular methods for the quality control of foods are a reality, and as such, deserve special attention with regard to their availability for the regulation of products subject to sanitary surveillance.

Polymerase chain reaction (PCR) is widely used for the detection of food pathogens. Due to its high sensitivity and specificity, PCR-based methods have the advantage of providing rapid and precise identification of the pathogen and can therefore serve as a powerful tool in the hygienic and sanitary assessment of açai-based foods.

Polymerase chain reaction requires a high-quality amplifiable deoxyribonucleic acid (DNA). Therefore, the choice of the method for DNA extraction is of great importance and constitutes a pre-requisite for molecular analysis. DNA amplification by PCR is influenced by the structural integrity of the DNA and the presence of matrix co-purification inhibitors or extraction reagents, which may reduce PCR efficiency.

In foods, the problems most often linked to DNA extraction include contamination by phenols and polysaccharides, among others. Açai is composed of lipids, carbohydrates, fiber, vitamin E, proteins, minerals $(\mathrm{Mn}, \mathrm{Fe}, \mathrm{Zn}, \mathrm{Cu}$, and $\mathrm{Cu}$ ), and antioxidant compounds such as anthocyanins, and phenolic compounds ${ }^{(11)}$, which pose a big challenge for DNA extraction from the parasites in such a complex food matrix.

In this context, the aim of this study was to compare the quantity and quality of T. cruzi DNA isolated from açai artificially contaminated with $T$. cruzi cells, whereby four different DNA extraction methods were applied, and spectrophotometric absorbance readings were used to confirm the quality of the extracted DNA by PCR amplification of the gp85 gene superfamily/sialidase.

\section{METHODS}

\section{Staining}

The stains used in the present work were for the identification of 1) Leishmania (Leishmania (V.) braziliensis MHOM/ BR/1975/M2903 - IOC-L 0566, Leishmania (L.) amazonensis IFLA/BR/1967/PH8 - IOC-L 575), Leishmania Collection (CLIOC/FIOCRUZ), Instituto Oswaldo Cruz; 2) Trypanosoma cruzi CL Brener, Instituto Nacional de Infectologia Evandro Chagas, Fundação Oswaldo Cruz (INI/FIOCRUZ); and 3) Trypanosoma rangeli COLPROT 273, Protozoa Collection (COLPROT/FIOCRUZ), Fundação Oswaldo Cruz.

\section{Artificial contamination of açai}

Labeled açai medium, one kilogram of frozen fruit pulp was purchased from a supermarket in Rio de Janeiro, Brazil and thawed at $4^{\circ} \mathrm{C}$. The pulp was then homogenized in a Seward Stomacher ${ }^{\circledR} 400$ Laboratory Blender (Seward, UK) and distributed in $50-\mathrm{mL}$ polypropylene vials. For each extraction method, five 30 -mL glass bottle vials received $2 \mathrm{~mL}$ of the homogenate of açai pulp and T. cruzi CL Brener with a cell suspension rate of 1,000 (Dilution 1), 100 (Dilution 2), 50 (Dilution 3), 10 (Dilution 4), and 5 (Dilution 5) parasite cells. This procedure was repeated three times, resulting in 15 glass bottles used per method. The homogenate of acai pulp and T. cruzi was subjected to a freezedrying for about 20 hours for reducing the volume of the mixture and for obtaining a lyophilisate to allow efficient extraction.

\section{DNA extraction}

Four different methods for genomic DNA extraction were tested as displayed in Table 1. Two of these were performed using cetyltrimethyl ammonium bromide (CTAB), as described by Cardarelli et al. $2005^{(12)}$ and the Joint Research Centre $2005^{(13)}$, and the other two were performed using commercially available agents, namely DNAzol ${ }^{\circledR}$ (Invitrogen) and Nucleo Spin ${ }^{\circledR}$ (MACHEREY-NAGEL), strictly in accordance with the manufacturer's recommendations. The extractions were performed in triplicate for each method as indicated in Table 1.

\section{Assessment of concentration and purity of the extracted DNA}

Deoxyribonucleic acid concentration was assessed by spectrophotometric measurement of the optical density (OD) at $260 \mathrm{~nm}$ using the GeneQuant TM equipment pro ribonucleic acid/deoxyribonucleic acid (RNA/DNA) calculator (Amersham Biosciences, UK). Ratios of the absorbance at A260/280 and A260/230 were determined to verify the purity of the preparations, which yielded samples that were found to be of acceptable quality and integrity.

\section{PCR for the detection of Trypanosoma cruzi}

Standardization of the PCR for evaluating its specificity was performed using strains of Leishmania chagasi, L. braziliensis, Trypanosoma rangeli, and T. cruzi, where a pair of T. cruzi-specific primers were employed to amplify a telomeric region of the gp $85 /$ sialidase superfamily (Tc189Fw2 - 5'CCAACGCTCCGGGAAAAC-3' and Tc189RV3 5'GCGTCTTCTCAGTATGGACTT-3'), as described by Chiurillo et al. ${ }^{(14)}$.

After standardization, the same protocol was used for the detection of T. cruzi in different concentrations of cells mixed with açai. The negative and positive controls used for the PCR were T. rangeli and T. cruzi, respectively. The fragments amplified by PCR were separated by agarose gel electrophoresis $(2 \% \mathrm{w} / \mathrm{v})$ containing $0.3 \mu \mathrm{g} / \mathrm{mL}$ ethidium bromide immersed in $1 \mathrm{X}$ tris-borato-ethylenediaminetetraacetic acid (TBE) buffer (90mM Tris-borate, 2mM EDTA pH 8, 4), visualized on the "UVP TM-20 Dual-Intensity transilluminator" (Cole-Parmer, US), and recorded in the image analyzer "Image Quant 300 Imager" (Amersham Biosciences, UK). 


\section{Validation of the selected DNA extraction method}

Eighteen glass bottles containing about $2 \mathrm{~mL}$ of açai were contaminated with 1,000 T. cruzi CL Brener cells and subjected to lyophilization. DNA was extracted according to the Join Research Centre (JRC) method, 2005, in 6 replicates, repeated for 3 consecutive days. After extraction, the concentration and purity of the extracted DNA were evaluated using the methods described above. The size of the extracted DNA was assessed by electrophoresis on $1 \%$ agarose gel. About $10 \mu \mathrm{L}$ of the DNA solution was deposited on an agarose gel in TBE $1 \mathrm{X}$ at $80 \mathrm{~V}$ for 1 hour.

\section{RESULTS}

The DNA extracted using the NucleoSpin ${ }^{\circledR}$ method showed no reading in the spectrophotometer. The average concentration of the DNA extracted from açai infected with $T$. cruzi cells using the other three methods is shown in Table 2.

All three methods yielded sufficient quantities of DNA to allow PCR detection. Although the DNA extracted using the DNAzol method produced a four times greater value (about $320 \mathrm{ng} / \mu \mathrm{L}$ ) than the other two methods using CTAB (about75ng/ $\mu \mathrm{L}$ ), the eluate with the extracted DNA had a brownish color due to the inefficiency of the method in eliminating the pigments present in açai. This may have led to overestimation of the DNA concentration and/or may have inhibited the PCR.

The purity of the DNA extracted using the three methods after the removal of outliers using the Grubbs test is shown in Table 2.

The A260/A280 ratio is used to test for the presence of proteins and thus helps estimate the purity of nucleic acids. For pure DNA, the value must be between 1.8 and 2.0. The A260/A230 reflects contamination by substances such as carbohydrates, peptides, phenols, and aromatic compounds. In the case of pure samples, the ratio should be above $2^{(15)}$.

With respect to the A260/A280 ratios obtained, the method using $\mathrm{CTAB}$, RNase, proteinase, and $70 \%$ ethanol washes was able to extract DNA with higher purity ${ }^{(13)}$. The DNA extracted using DNAzol proved to exhibit a high protein contamination ratio, with values appreciably below 1.8 .

With reference to the A260/A230 ratio, the method that came closest to the expected value was the CTAB method ${ }^{(13)}$. The use of DNAzol resulted in values far below expectation, wherein the DNA extracted showed a high degree of chemical contamination. The specificity of PCR for T. cruzi DNA was established with all four strains belonging to the Trypanosomatidae family (Figure 1).

Five dilutions of the DNA extracted using the CTAB method $^{(13)}$ allowed PCR amplification; the results can be observed both in Table 2 and in Figure 2.

The result of the validation of the 18 replicas (first day: 69.2, 66.0, 69.4, 72.4, 84.6, 84.4; second day: 78.2, 52.4, 61.0, 75.2, 54.0, 63.6; and third day: 73.4, 66.6, 76.0, 63.0, 87.2, 74.6) bears out an average of $70.6 \mathrm{ng} / \mu \mathrm{L}$, a standard deviation of $9.8 \mathrm{ng} / \mu \mathrm{L}$, and a coefficient of variation of $13.9 \%$. No PCR inhibition was observed in the agarose gel, and amplicons of $100 \mathrm{bp}$ were generated in all the 18 replicates (Figure 3). 
TABLE 2 - Evaluation of the average standard deviation with concentrations and coefficient of variation (\%), along with purity using absorbance readings at 230, 260, and $280 \mathrm{~nm}$ of DNA extracted from açai contaminated with Trypanosoma cruzi.

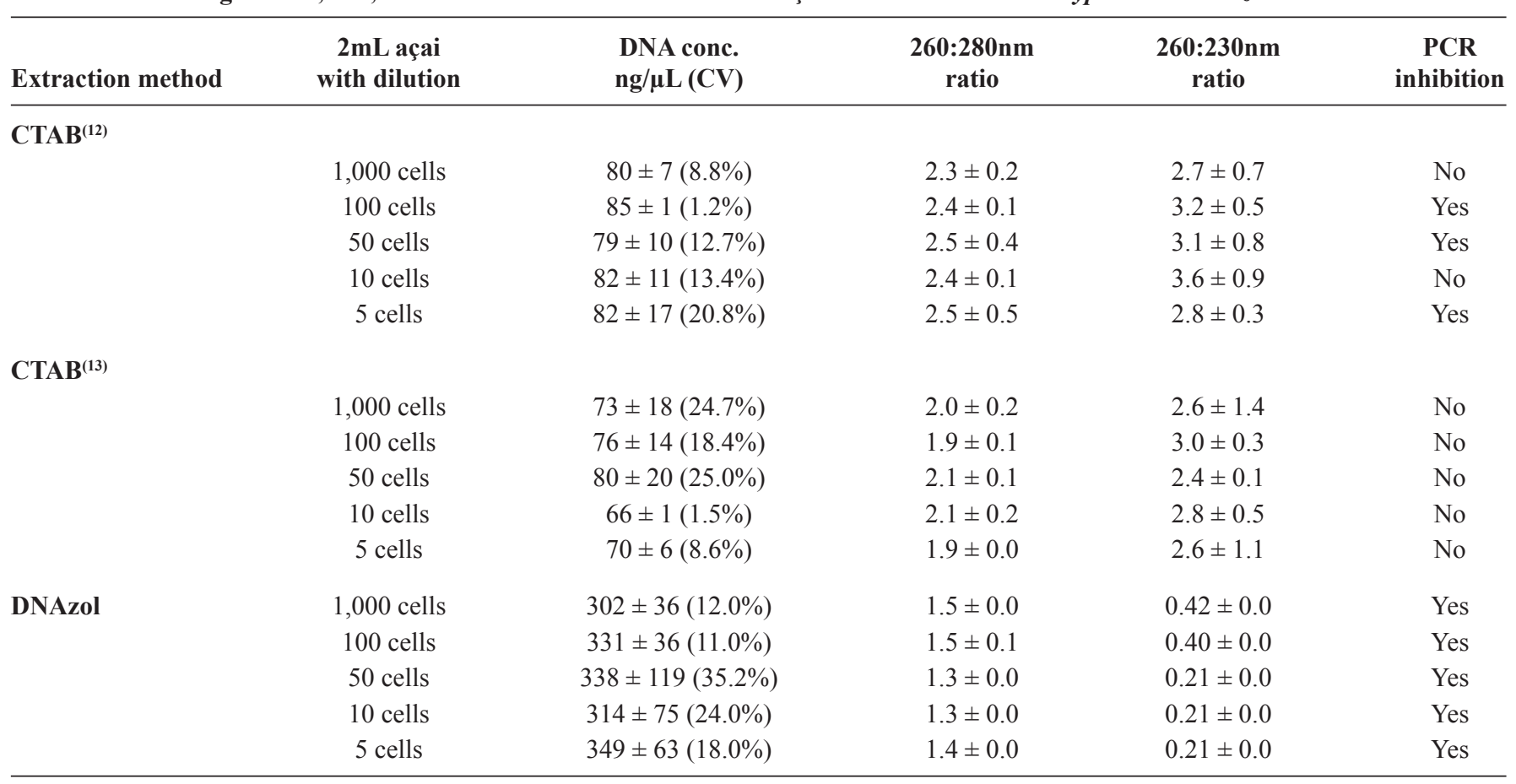

DNA: deoxyribonucleic acid; CV: coefficient of variation; PCR: polymerase chain reaction; CTAB: cetyltrimethyl ammonium bromide.

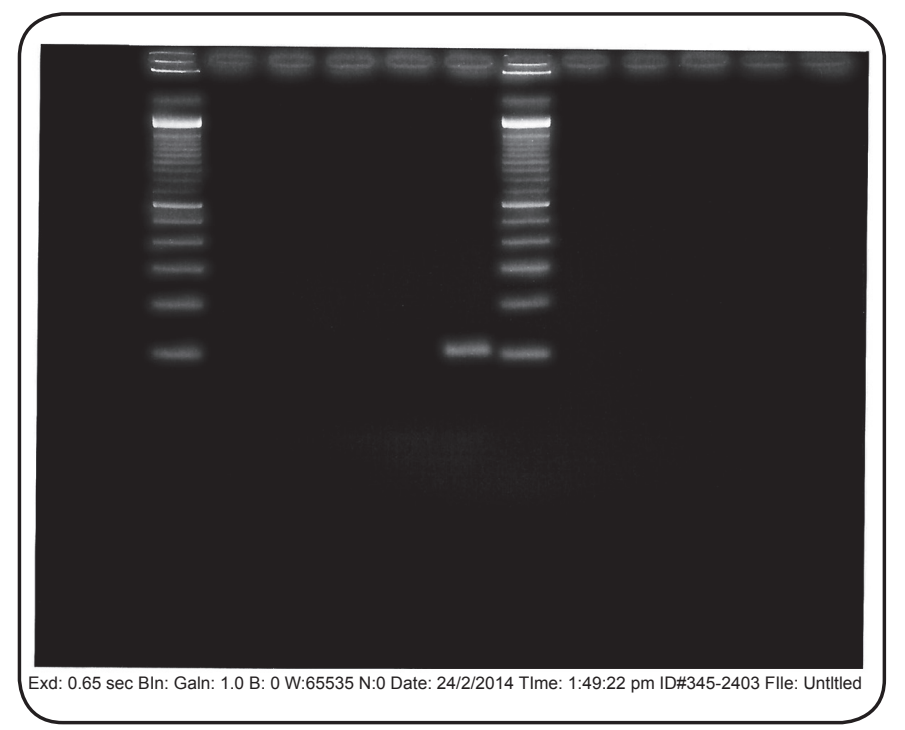

FIGURE 1 - Specificity of PCR for Trypanosoma cruzi established with four strains belonging to the Trypanosomatidae family. Lanes 1 and 7: contain a 100-bp size ladder (Gibco-BRL); Lane 2: H2O; Lane 3: Leishmania amazonensis; Lane 4: Leishmania braziliensis; Lane 5: Trypanosoma rangeli; Lane 6: Trypanosoma cruzi cL Brener. PCR: polymerase chain reaction.

\section{DISCUSSION}

To date, no studies evaluating a methodology for $T$. cruzi DNA extraction directly from food have been conducted. This study was aimed at identifying an efficient method for the extraction of T. cruzi DNA from T. cruzi-contaminated acai. Although the Nucleo Spin method has been developed for various types of food such as chocolate-based products and fruit concentrates, among others, it was shown to not be adequate for the detection T. cruzi contamination in this study. DNA extraction by the CTAB method yielded satisfactory results with regard to purity and concentration for use in PCR.

The method employing the CTAB detergent for cell lysis is widely used for genetically modified organisms (GMO) analysis of raw or processed food; it is also commonly used for plants, especially in combination with other substances such as $\beta$-mercaptoethanol ${ }^{(16)(17)(18)}$. The major difference between the two methods using the CTAB detergent for cell lysis tested in this study was the use of two different enzymes, RNases and Proteinase K, and the $70 \%$ ethanol wash ${ }^{(13)}$, which confirms the high sensitivity of the method with amplification of up to 2.5 cells $/ \mathrm{mL}$ of acai.

Contamination of food by $T$. cruzi may occur especially when triatomines deposit their droppings on the surface of infected food or food ingredients, or when these triatomines are crushed with foods, mainly during fruit juice processing, such as in the processing of açai juice.

Equally important in the epidemiology of foodborne acute Chagas disease (ACD) is the contamination of equipment and utensils, contamination during transport, and contamination in the food processing environment, where it typically occurs by either urine or anal secretions of marsupials as well as by feces of infected bugs caused due to human invasion of forests ${ }^{(5)(10)(19)}$. 


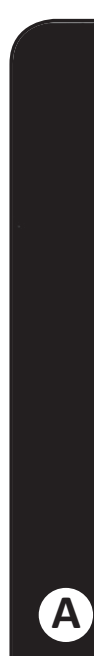

Exd: 1.9 Bln: 1x1 Galn: 1.0 B: 0 W: 255 G:0.55 N:0 Date: 30/4/2013 Time: 2:35:04 pm ID\#345-852 File:E:rENATA 30-04-2013.jpg

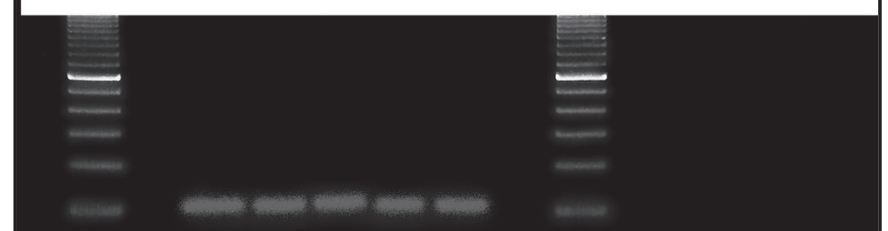

B

Exd: 0.96sec Bln: 1x1 Galn: 1.0 B:0 W:65535 G:0.75 N: 0 Date: 22/8/2013 TIme: 3:39:54 pm ID:\#345-1428 File: Unttled

FIGURE 2 - PCR amplification of the DNA extracted from the homogenate of açai with Trypanosoma cruzi $\mathrm{cL}$ Brener with a cell suspension rate of 1,000 to 5 parasite cells using 3 extraction methods. A) Lanes 1 to 5: DNAzol extraction method (no amplification); Lane 6: 100-bp size ladder (Gibco-BRL); Lanes 7 to 11: CTAB extraction method ${ }^{(12)}$; Lane 12: Trypanosoma cruzi $\mathrm{cL}$ Brener (positive control). B) Lanes 1 and 9: 100-bp size ladder (Gibco-BRL); Lanes 3 to 7: CTAB extraction $\operatorname{method}^{(13)}$. PCR: polymerase chain reaction; DNA: deoxyribonucleic acid; CTAB: cetyltrimethyl ammonium bromide.

So far, it has not been possible to analyze the type of food involved in the outbreaks of orally transmitted Chagas disease to evidence the presence of the parasite. However, as quoted above, PANAFTOSA ${ }^{(19)}$ proposes hypotheses that point to an explanation for the several outbreaks that have occurred in recent years in Northern Brazil, which were associated with the intake of possibly T. cruzi-contaminated açai juice.

The recorded cases of ACD in the outbreaks are related to the consumption of handmade acai juice.

In Latin America, around 100 million individuals suffer from Chagas disease acquired by various types of transmission. Additionally, the estimated number of people infected with T. cruzi in non-endemic countries for the disease is $>300,000$ in the

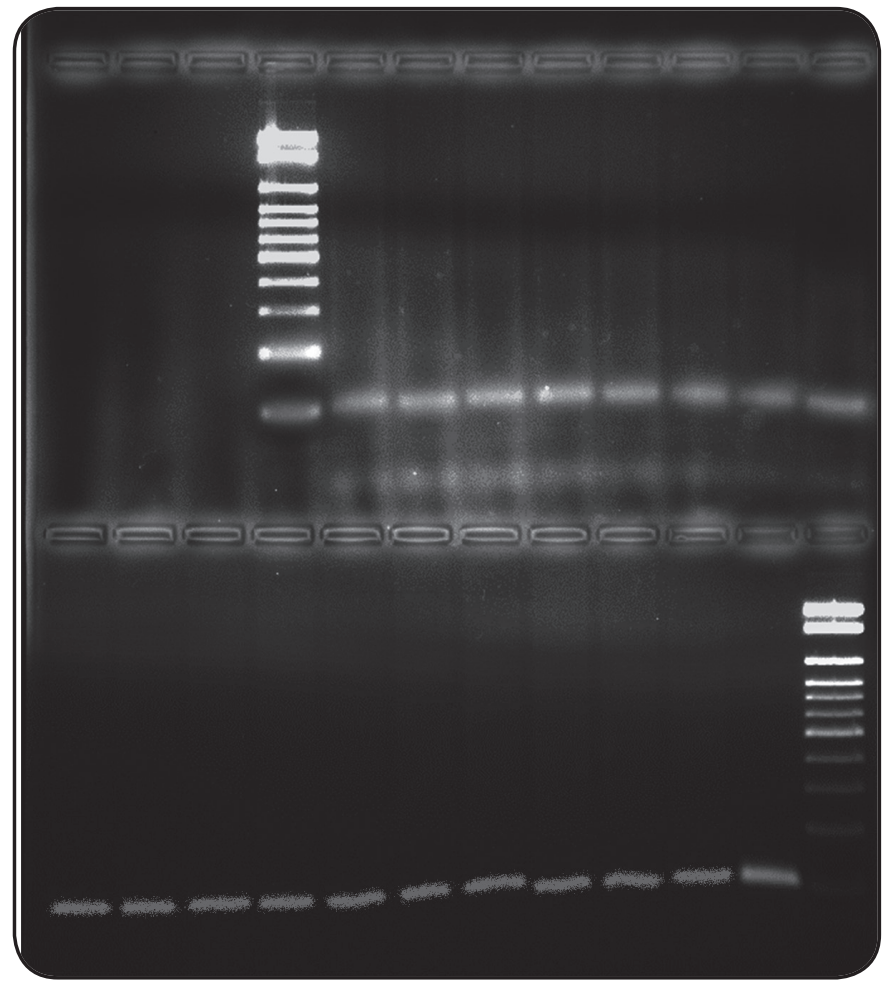

FIGURE 3 - Agarose gel electrophoresis of all the 18 amplified products obtained from the validation assay with primers Tc189Fw2 and Tc189Rv3. Top - Lane 1: H2O; Lane 2: Trypanosoma rangeli (negative control); Lane 3: 100-bp size ladder (Gibco-BRL); Lanes 4 to 10: homogenate of açai with Trypanosoma cruzi CL Brener with a 100-cell suspension. Bottom Lanes 1 to 10: homogenate of açai with Trypanosoma cruzi CL Brener with a 100-cell suspension; Lane 11: T. cruzi cL Brener (positive control); Lane 12: 100-bp size ladder.

United States; $>5,500$ in Canada; $>80,000$ in Europe and Western Pacific Regions; $>3,000$ in Japan; and $>1,500$ in Australia ${ }^{(20)}$. Migratory movements and the subsequent transmission by blood transfusion and organ transplantation have been suggested as the cause of the spread of T. cruzi around the World.

In Brazil, 2 million individuals are infected with T. cruzi $^{(21)}$. Considering the high consumption of açai by tourists visiting the country, plus Brazilians themselves traveling to the abovementioned non-endemic areas of the world, the oral transmission is assumed to be contributing to the increase in overseas cases. This assumption is rooted in the fact that, having acquired the asymptomatic disease, or even the manifestation of symptoms similar to those of other types of illnesses, visitors to Brazil are likely to return to their countries where blood banks may not be equipped with the proper framework required to provide an effective diagnosis of the disease.

Barbosa-Labello et al, in 2010 (22), used animal models to show that, in addition to surviving in açai pulp by different incubation periods and under different low temperatures treatments, $T$. cruzi was also able to preserve its virulence in mice. Regarded to be of great epidemiological importance, this finding discards the use of cooling processes and conventional freezing during long periods, which have been previously used as control methods 
for orally transmitted ACD. This finding also reinforces the need to use bleaching as for the conservation of açai.

In consideration of the above findings, safety measures must be taken at all stages of the commercial or craft supply chain during the processing of açai. The development of large-scale detection and isolation methods for $T$. cruzi in food products is essential so that epidemiological evidence may serve as supporting data to certify that the food in question is actually contaminated with the parasite. Concurrently, despite the fact that DNA identification in foods itself does not constitute a methodology to assess the viability of the parasite, it can become an assessment tool to ensure proper application of good manufacturing practices.

In the case of açai, these tests will allow the identification of possible contamination during the production chain. This procedure is of great importance since oral transmission aggravates an epidemic of the disease, and disposes off refrigeration and food freezing processes as control methods for the oral transmission of ACD, thus inducing a new reflection, strongly related to underdevelopment ${ }^{(3)}$.

\section{ACKNOWLEDGMENTS}

The authors thank Dra Maria de Fátima Madeira from Instituto Nacional de Infectologia Evandro Chagas/Fundação Oswaldo Cruz (INI/FIOCRUZ) for their support in cultivating strains of trypanosomatídeos.

\section{CONFLICT OF INTEREST}

The authors declare that there is no conflict of interest.

\section{REFERENCES}

1. Ferreira RTB, Branquinho MR, Cardarelli-Leite P. Transmissão oral da doença de Chagas pelo consumo de açaí: um desafio para a vigilância sanitária. Vigil Sanit Debate 2014; 2:4-11.

2. Ministério da Saúde. Agência Nacional de Vigilância Sanitária. Informe Técnico $\mathrm{n}^{\circ} 35$ de 19 de junho de 2008. Gerenciamento do Risco Sanitário na Transmissão de Doença de Chagas Aguda por Alimentos (Internet). Brasília: Ministério da Saúde; 2008 (Cited 2009 November 11). Available at: http://portal.anvisa. gov.br/wps/content/Anvisa+Portal/Anvisa/Inicio/Alimentos/ Assuntos+de+Interesse/Informes+Tecnicos/2008-06-19-35

3. Passos LAC, Guaraldo AMA, Alves DP. Relatório final, convênio 667/ 2008 com Ministério da Saúde: "Análise da interferência da polpa de açaí na transmissão oral de Trypanosoma cruzi, contribuindo para o surgimento de surtos de Doença de Chagas Aguda (DCA) na região Norte do Brasil“". Campinas, SP; 2010.

4. Pereira KS, Schmidt FL, Guaraldo AMA, Franco RMB, Dias VL, Passos LAC. Chagas disease as a food borne illness. J Food Protect 2009; 72:441-446.

5. Valente SAS, Valente VC, Pinto AYN, César MJB, Santos MP, Miranda COS, et al. Analysis of an acute Chagas disease outbreak in the Brazilian Amazon: human cases, triatomines, reservoir mammals and parasites. Trans R Soc Trop Med Hyg 2009; 103: 291-297.
6. Homma AKO, Nogueira OL, Menezes AJEA, Carvalho JEU, Nicoli CML, Matos GB. Açaí: Novos desafios e tendências. Amazônia: Ci \& Desen 2006; 1:7-23.

7. Menezes EMS, Torres AT, SabaaSrur AU. Valor nutricional da polpa de açaí (Euterpe oleracea Mart.) liofilizada. Acta Amaz 2008; 38:311-316.

8. Ministério da Agricultura e do Abastecimento. Instrução Normativa $n^{\circ} 1$, de 7 de janeiro de 2000. Regulamentação técnica para fixação dos padrões de Identidade e Qualidade para polpas de frutas. Diário Oficial da União, 10 jan. 2000. Brasília: Ministério da Agricultura e do Abastecimento; 2000.

9. Empresa Brasileira de Pesquisa Agropecuária (EMBRAPA). Sistema de produção do açaí. (Internet). Brasília, DF: 2008 (Cited 2013 November 1). Available at: http://sistemasdeproducao.cnptia.embrapa.br/FontesHtML/ Acai/SistemaProducao Acai_2ed/paginas/apresentacao.htm.

10. Perez-Gutierrez E, Salvatella R, Figueroa R (orgs). Consulta técnica em epidemiologia, prevenção e manejo da transmissão da doença de Chagas como doença transmitida por alimentos. Relatório Técnico. PANAFTOSA; Rio de Janeiro, 2006. Rev Soc Bras Med Trop 2006; 39:512-514.

11. Portinho JA, Zimmermann LM, Bruck MR. Beneficial effects of açaí. Int J Nutrol 2012; 5:15-20.

12. Cardarelli-Leite P, Branquinho MR, Ferreira RTB. Detection of GMO in food products in Brasil: the INCQS experience. Food control 2005; 16:859-866.

13. Join Research Centre (JRC). Event-specific method for the quantification of maize line NK603 using real-time PCR protocol. (Internet). 2005 (Cited 2015 October 1). Available at: http://gmocrl.jrc.ec.europa.eu/statusofdoss.htm.

14. Chiurillo MA, Crisante G, Rojas A, Peralta A, Dias M, Guevara, et al. Detection of Trypanosoma cruzi and Trypanosoma rangeli Infection by duplex PCR assay based on telomeric sequences. Clin Diagn Lab Immunol 2003; 10:775-779.

15. Corbisier P, Broothaerts W, Gioria S, Schimmel H, Burns M, Baoutina A, et al. Toward metrological traceability for DNA fragment ratios in GM quantification. 1. Effect of DNA extraction methods on the quantitative determination of Bt 176 corn by RealTime PCR. J Agric Food Chem 2007; 55:3249-3257.

16. Devi KD, Punyarani K, Singh NS, Devi HS. An efficient protocol for total DNA extraction from the members of order Zingiberalessuitable for diverse PCR based downstream applications. Springer Plus 2013; 2:669.

17. Minas K, McEwan NR, Newbold CJ, Scott KP. Optimization of a high-throughput CTAB-based protocol for the extraction of qPCRgrade DNA from rumen fluid, plant and bacterial pure cultures. Fems Microbiol Lett 2011; 325:162-169.

18. Mondal TK, Ganie SA. Identification and characterization of salt responsive miRNA-SSRmarkers in rice (Oryza sativa). Gene 2014; 535:204-209.

19. Organização Panamericana de Saúde, Organização Mundial de Saúde, PANAFTOSA-VP. Guia para vigilância, prevenção, controle e manejo clínico da doença de Chagas aguda transmitida por alimentos. Rio de Janeiro: PANAFTOSA-VP/OPAS/OMS; 2009.

20. Coura JR, Viñas PA. Chagas disease: a new worldwide challenge. Nature 2010; 465:56-57.

21. World Health Organization. Crompton DWT, Peters P, editors. Working to Overcome the Global Impact of Neglected Tropical Diseases: First WHO Report on Neglected Tropical Diseases. Nonserial Publication Series. WHO report on neglected tropical diseases. volume 1; 2010. 172p.

22. Barbosa-Labello R. Transmissão oral do Trypanosoma cruzi pela polpa de açaí em camundongos. 2010 [dissertation]. [São Paulo]: Universidade Estadual de Campinas; 2010. 120 p. 